\title{
EFFECT OF DIFFERENT ACCESSIONS ON YIELD CONTRIBUTING CHARACTERS AND YIELD OF STRAWBERRY UNDER DIFFERENT GROWING CONDITION
}

\author{
Md. Shamsul Alam ${ }^{1 \star}$, Md. Rafiqul Islam ${ }^{2}$ and Sadia Afrin ${ }^{3}$ \\ ${ }^{1}$ Senior Scientific Officer, Horticulture Division, Bangladesh Institute of Nuclear Agriculture (BINA), \\ Mymensingh-2202, Bangladesh; ${ }^{2} \mathrm{SSO}$ and Head, Horticulture Division, Bangladesh Agricultural University, \\ Mymensingh-2202, Bangladesh; ${ }^{3}$ Research Assistant, VDB Project, Horticulture Division, Bangladesh \\ Institute of Nuclear Agriculture (BINA), Mymensingh-2202, Bangladesh.
}

*Corresponding author: Md. Shamsul Alam; E-mail:mithuhort@yahoo.com

\section{ARTICLE INFO}

A B S T R A C T

Received

30 July, 2019

An experiment was conducted at Bangladesh Institute of Nuclear Agriculture (BINA), Horticulture Division farm, BINA, Mymensingh on effect of different accessions on yield contributing characters and yield of strawberry under different growing conditions during October, 2016 to April, 2017. The twofactor experiment had two levels of planting conditions (Factor A) and three strawberry accessions

Revised (Factor B) as follows -Factor A- Planting conditions: a) pot condition and b) field condition and Factor B

12 August, 2019 - strawberry accessions: accession-1( RABI strawberry-1), accession-2 (New York, USA) and accession-3(Kagawa, Japan). The experiment was conducted in randomized complete block design

Accepted 24 August, 2019 with 3 replications. Results showed that accession- 2 revealed the highest results almost all yield contribution characters and yield parameters. The tallest plant $(29.78 \mathrm{~cm})$, the highest number of leaves

Online (46.35), longest leaf $(26.58 \mathrm{~cm})$, no. of inflorescences (15.95), number of flowers per inflorescence

31 August, 2019 (8.21), number of fruit per inflorescences $(7.45)$, diameter of fruit $(4.25 \mathrm{~cm})$, fresh weight of fruit $(22.17$ $\mathrm{g})$, total soluble solids $(18.54 \%)$, yield (g/plot) $(400.3 \mathrm{~g})$ and yield per hectare $(21.72 \mathrm{t} / \mathrm{ha})$ were recorded from accession-2. But number of seeds per fruit (217.0) was observed from accession -1. The

Key words lowest values were found on all the mentioned parameters in accession-3.The significant difference between the growing conditions was observed on all the mentioned parameters. The highest yield

Growing condition Growth

Pot (20.12 t/ha) per hectare and yield contributing characters were noted in field condition and the lowest values on all the mentioned parameters were obtained in pot condition. Statistically significant variations were found on all the mentioned parameters due to combined effect. The tallest plant $(30.33$ $\mathrm{cm})$, highest number of leaves per plant $(47.36)$, longest leaf $(27.64 \mathrm{~cm})$, number of inflorescences

Strawberry

Yield (16.66), number of flowers per inflorescences (8.99), number of fruit per inflorescences (7.68), individual weight of fruit $(25.19 \mathrm{~g})$, total soluble solids (18.98), yield per plot $(482.6 \mathrm{~g})$, yield per hectare $(24.37 \mathrm{t} / \mathrm{ha})$ were found in accession-2 under field condition. The highest diameter of fruit $(4.50 \mathrm{~cm})$ was found in accession-3 in field condition which was statistically similar with accession-2 both in field condition and pot condition. The maximum number of seeds per fruit (217.0) was recorded from accession-3 both in pot and field condition. But accession-2 gave the minimum number of seeds per fruit (118.0) under field condition.

To cite this article: Alam MS, M R Islam and S Afrin, 2019. Effect of different accessions on yield contributing characters and yield of strawberry under different growing condition. Res. Agric. Livest. Fish. 6 (2): 171-179.

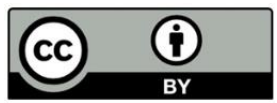




\section{INTRODUCTION}

Strawberry (Fragaria sp) is belonging to the family Rosaceae, is one of the most delicious and sweet flavored fruit throughout the world. Though it is a major fruit of temperate region but it can be grown even in both tropical and subtropical region (Ram et al., 2009) and the area under this crop in the sub-continent is increasing rapidly (Singh and Asrey, 2009). Strawberries were the 19th most important fruit crop worldwide with approximately 8.367 Million metric tons produced on 395,844 hectares of land (FAOSTAT, 2018). The leading countries of strawberry cultivation are the China (7489.63 thousand MT) and U.S.A. (2880.33 thousand metric tons by $2016-2017$ total production (FAO, 2018). It has a unique place among all the berry fruits because of its charming red color, nutritive value ( Sharma et al., 2013) and enriched with organic and vitamins (Sharma, 2002). The attractive strawberry fruits are favored for their excellent taste and contain health promoting vitamins, minerals and ant oxidative compounds (Hannum, 2004). Strawberries have been introduced in Bangladesh recently and getting popularity with a very small scale cultivation (Chowdhury et al, 2013). It grows well in the winter especially October- November is the best time for its planting so that it can complete its life cycle before March (Hossain, 2009). Being a winter season crop, it has to face a lot of natural advertise like poor soil moisture, temperature fluctuation and so on specially during flowering and fruiting ( Sharma et al., 2013). In Bangladesh strawberry fruit production is dominated by only few cultivars as it is the exotic fruit in the country. Strawberries are producing well in our Bangladeshi adverse condition but shelf life is very poor. Suitable germplasm is a limiting factor for strawberry because of the short winter in Bangladesh and furthermore the production of strawberry depends greatly on the day temperature, humidity, growing condition and day length. In order to improve cultivars and growing condition farmers have to meet new problems of cultivation. Hence, the present research experiment has been planned and designed with the following objectives (1) to assess and select appropriate germplasm for a potential growth and yield of strawberry and (2) to select the appropriate growing condition for increased growth and yield.

\section{MATERIALS AND METHODS}

An experiment was conducted at BINA Head Quarter, Horticulture Division farm, Bangladesh Institute of Nuclear Agriculture (BINA), Mymensingh on the effect of different accession on yield contributing characters and yield of strawberry under different growing condition during October, 2016 to April 2017. The 2-factor experiment had two levels of planting conditions (Factor A) and three strawberry accessions (Factor B) as follows -Factor A- Planting conditions: a) pot condition and b) field condition; Factor B - strawberry accessions: accession-1(RABI strawberry-1), accession-2 (New York, USA) and accession-3(Kagawa, Japan). The pot size was 1 feet $\times 11$ ". For field condition, unit plot size was $1.5 \mathrm{~m} \times 1 \mathrm{~m}$; plant spacing: $50 \mathrm{~cm} \times$ $20 \mathrm{~cm}$; total number of treatments: $2 \times 3=6$; total number of unit plots: $6 \times 3=18$; total number of plants per plot = 24; date of planting: 9 Nov., 2016. The experiment was conducted in randomized complete block design (RCBD) with 3 replications. Three strawberry accessions where RABI strawberry-1 collected from Department of Botany, Rajshahi University; New York and Kagawa variety collected from USA and Japan, respectively were used as planting materials. Intercultural operations were done as and when necessary. The following data (height of plant, number of leaves per plant, length of longest leaf per plant, number of inflorescence per plant, number of flower per inflorescences, number of fruit per inflorescence, diameter of fruit, fresh weight of individual fruit per plant, TSS, number of seeds per fruit, yield per plot and yield per hectare) on physiomorphological growth parameters after planting as well as on yield were recorded and continued up to final harvest. The means for all treatments were calculated and the analyses of variances for all the characters under consideration were performed by ' $F$ ' variance test. The significance of difference between pair of means was performed by Least Significant Difference (LSD) test taking 5\% probability level as the minimum unit of significance (Gomez and Gomez, 1984). 


\section{RESULTS AND DISCUSSION}

A standardized ontology for phenotypic and genotypic characterization of the collection and an optimized documentation of the evaluated data is required to improve accessibility of the available genetic resources. The present investigation had marked influence on height of plant, number of leaves per plant, length of longest leaf, fresh weight of individual fruit, diameter of fruit, and number of inflorescences per plant, number of flower per inflorescences, number of fruit per inflorescences, TSS and yield of bulb per hectare during growth period as well as at final harvest. Results of the analyses of variance in respect of all parameters obtained from the present investigation have been presented and discussed.

\section{Plant height}

Plant height was varied significantly by the accessions effect. The tallest plant $(29.78 \mathrm{~cm})$ was observed in Accession-2 (New York, USA). Conversely, the shortest $(22.51 \mathrm{~cm})$ plant was recorded in Accession-1. Result revealed that during the growth period the length gradually increased with the advancement of growth time and started to decrease after mature stage. This result was supported by Paul et al. (2017) where Rabi Strawberry-1 was also performed lowest $(16.5 \mathrm{~cm})$. There was a significant variation between pot and field growing condition. The highest $(26.71 \mathrm{~cm})$ plant height was noted from field condition and the lowest $(25.28 \mathrm{~cm})$ was recorded in pot condition (Table 2). This result indicates that the plant heights of different strawberry varieties were not same and this character was genetically controlled. An increase in plant height was recorded with the widely spaced soil containing abundant with nutrient. The influence of combined effect of different accessions and planting conditions in respect of height of plant was found to be significant. The tallest $(30.33 \mathrm{~cm})$ plants were obtained from the field in accession-2 and the lowest height of plant $(22.20 \mathrm{~cm})$ was found in accession-1 (RABI strawberry-1) in pot condition (Table 3).

\section{No. of leaves/plant}

No. of leaves were significantly affected by the accessions. Maximum number of leaves (46.35) per plant was found in accession-2 while minimum (38.07) number of leaves was observed from accession-1 (RABI strawberry-1) (Table 1).The highest (11.2) number of leaves per plant was observed in variety BARI strawberry-1 and the lowest (10.66) number of leaves per plant was observed in Rabi strawberry-1. This result agrees with Paul et al. (2017). The significant difference between the planting conditions was observed in number of leaves per plant. The number of leaves was the highest (43.15) at field condition and the lowest (41.87) at pot condition (Table 2). Statistically significant variations were found in number of leaves per plant due to combined effect. The highest (47.36) number of leaves per plant was noted from accession-2 (New York, USA) in field condition and the lowest (37.17) was recorded in accession-1 (RABI strawberry-1) in pot condition (Table 3).

\section{Length of longest leaf/plant}

The accessions showed highly significant in respect of length of longest leaf. The longest leaf $(26.58 \mathrm{~cm})$ was obtained from accession-2 (New York, USA) and the lowest leaf length $(21.28 \mathrm{~cm})$ was obtained from accession-1 (RABI strawberry-1) (Table 1). The longest leaf was significantly influenced showing highest value $(24.55 \mathrm{~cm})$ at field condition and lowest $(22.41 \mathrm{~cm}$ ) value at pot condition (Table 2). Different combined treatment showed significant variations in case of length of longest leaf per plant. The longest leaf $(27.64 \mathrm{~cm})$ was found in accession-2 (New York, USA) in field condition. On the other hand, the lowest leaf length $(20.10$ $\mathrm{cm}$ ) was recorded from accession-1 (RABI strawberry-1) in pot condition (Table 3).

\section{No. of inflorescences / plant}

A highly significant variation in respect of no. of inflorescences per plant was observed due to the effect of different accession of strawberry. No. of inflorescences was found to be the maximum (15.95) in accession-2 (New York, USA) and the minimum (10.84) was observed in accession-1 (RABI strawberry-1) (Table.1). This finding showed similarity with Jensen and Hancock (1982). The maximum (14.59) no. of inflorescences per plant was observed in field condition and minimum (12.56) was noted in pot condition which was revealed significantly different (Table 2). There was a significant difference in the number of inflorescences per plant due to different combination of accession and pot condition. The highest number of inflorescences (16.66) was obtained from accession-2 (New York, USA) in field condition and the lowest (9.11) was in accession-1 (RABI strawberry-1) in pot condition (Table 3). 
Table 1. Effects of different accessions on yield contributing characters and yield of strawberry

\begin{tabular}{|c|c|c|c|c|c|c|c|c|c|c|c|c|}
\hline Germplasm & $\begin{array}{l}\text { Plant } \\
\text { height } \\
\text { (cm) }\end{array}$ & $\begin{array}{l}\text { No. of } \\
\text { leaves/ } \\
\text { plant }\end{array}$ & $\begin{array}{l}\text { Length } \\
\text { of } \\
\text { longest } \\
\text { leaf }\end{array}$ & $\begin{array}{l}\text { No. of } \\
\text { infloresce } \\
\text { nces / } \\
\text { plant }\end{array}$ & $\begin{array}{l}\text { No. of } \\
\text { flower/ } \\
\text { inflores } \\
\text { cence }\end{array}$ & $\begin{array}{l}\text { No. of } \\
\text { fruit/ } \\
\text { infloresc } \\
\text { ences }\end{array}$ & $\begin{array}{l}\text { Diameter } \\
\text { of fruit } \\
(\mathrm{cm})\end{array}$ & $\begin{array}{l}\text { Fresh wt } \\
\text { of } \\
\text { individua } \\
\text { I fruit }\end{array}$ & $\begin{array}{l}\text { TSS } \\
(\%)\end{array}$ & $\begin{array}{l}\text { No. of } \\
\text { seeds/ } \\
\text { fruit }\end{array}$ & $\begin{array}{l}\text { Yield } \\
\text { /plot (g) }\end{array}$ & $\begin{array}{l}\text { Yield } \\
\text { (t/ha) }\end{array}$ \\
\hline $\begin{array}{l}\text { Accession-1 } \\
\text { (RABI } \\
\text { strawberry-1) }\end{array}$ & $22.51 \mathrm{c}$ & $38.07 \mathrm{c}$ & $21.28 c$ & $10.84 c$ & $5.45 c$ & $5.99 \mathrm{c}$ & $3.56 b$ & $18.33 c$ & $15.96 c$ & $182.5 b$ & $275.0 \mathrm{c}$ & $14.94 \mathrm{c}$ \\
\hline $\begin{array}{l}\text { Accession-2 } \\
\text { (New York, } \\
\text { USA) }\end{array}$ & $29.78 a$ & $46.35 a$ & $26.58 a$ & $15.95 a$ & $8.21 \mathrm{a}$ & $7.45 a$ & $4.25 a$ & $22.17 a$ & $18.54 a$ & $119.0 \mathrm{c}$ & $400.3 a$ & $21.72 \mathrm{a}$ \\
\hline $\begin{array}{l}\text { Accession-3 } \\
\text { (Kagawa, Jp) }\end{array}$ & $25.69 \mathrm{~b}$ & $43.11 b$ & $22.58 \mathrm{~b}$ & $13.94 b$ & $6.86 \mathrm{~b}$ & $6.62 b$ & $4.25 a$ & $20.24 b$ & $16.97 b$ & $217.0 \mathrm{a}$ & $325.9 b$ & $17.72 b$ \\
\hline LSD at $5 \%$ & 0.94 & 0.56 & 0.95 & 0.64 & 0.56 & 0.34 & 0.38 & 0.27 & 0.30 & 6.65 & 5.86 & 0.37 \\
\hline $\begin{array}{l}\text { Level of } \\
\text { significance }\end{array}$ & * & * & * & * & * & * & * & * & * & * & * & * \\
\hline
\end{tabular}

Same letter indicates not significant within the values at $5 \%$ level of significance *indicates $5 \%$ level of significance 
Table 2. Effects of growing conditions on yield contributing characters and yield of strawberry

\begin{tabular}{|c|c|c|c|c|c|c|c|c|c|c|c|c|}
\hline $\begin{array}{l}\text { Planting } \\
\text { condition }\end{array}$ & $\begin{array}{l}\text { Plant } \\
\text { height } \\
(\mathrm{cm})\end{array}$ & $\begin{array}{l}\text { No. of } \\
\text { leaves / } \\
\text { plant }\end{array}$ & $\begin{array}{l}\text { Length } \\
\text { of } \\
\text { longest } \\
\text { leaf }\end{array}$ & $\begin{array}{l}\text { No. of } \\
\text { infloresce- } \\
\text { nces / } \\
\text { plant }\end{array}$ & $\begin{array}{l}\text { No. of } \\
\text { flower/ } \\
\text { infloresce- } \\
\text { nces }\end{array}$ & $\begin{array}{l}\text { No. of } \\
\text { fruit/ } \\
\text { infloresce- } \\
\text { nces }\end{array}$ & $\begin{array}{l}\text { Diameter } \\
\text { of fruit } \\
(\mathrm{cm})\end{array}$ & $\begin{array}{l}\text { Fresh } \\
\text { weight of } \\
\text { individual } \\
\text { fruit }\end{array}$ & $\begin{array}{l}\text { TSS } \\
\text { (\%) }\end{array}$ & $\begin{array}{l}\text { No. of } \\
\text { seeds/ } \\
\text { fruit }\end{array}$ & $\begin{array}{l}\text { Yield } \\
\text { / plot }(\mathrm{g})\end{array}$ & $\begin{array}{l}\text { Yield } \\
\text { (t/ha) }\end{array}$ \\
\hline Pot condition & $25.28 \mathrm{~b}$ & $41.87 \mathrm{~b}$ & $22.41 \mathrm{~b}$ & $12.56 \mathrm{~b}$ & $6.40 \mathrm{~b}$ & $6.41 \mathrm{~b}$ & $3.90 \mathrm{~b}$ & $17.26 \mathrm{~b}$ & $16.79 \mathrm{~b}$ & $\begin{array}{l}172.33 \\
a\end{array}$ & $269.07 b$ & $16.14 b$ \\
\hline $\begin{array}{l}\text { Field } \\
\text { condition }\end{array}$ & $26.71 a$ & $43.15 a$ & $24.55 a$ & $14.59 a$ & $7.28 \mathrm{a}$ & $6.97 a$ & $4.14 a$ & $23.23 a$ & $17.52 a$ & $\begin{array}{l}173.33 \\
a\end{array}$ & $398.41 a$ & $20.12 a$ \\
\hline LSD at $5 \%$ & 0.77 & 0.45 & 0.79 & 0.52 & 0.46 & 0.28 & 0.31 & 0.22 & 0.25 & 5.48 & 4.79 & 0.30 \\
\hline $\begin{array}{l}\text { Level of } \\
\text { significance }\end{array}$ & * & * & * & * & * & * & * & * & * & NS & * & * \\
\hline
\end{tabular}

Same letter indicates not significant within the values at $5 \%$ level of significance *indicates $5 \%$ level of significance; NS= Non significant 
Table 3. Combined effect of accession and planting condition for high yield potential

\begin{tabular}{|c|c|c|c|c|c|c|c|c|c|c|c|c|}
\hline $\begin{array}{l}\text { Treatment } \\
\text { combinatio } \\
\text { n }\end{array}$ & $\begin{array}{l}\text { Plant } \\
\text { height } \\
(\mathrm{cm})\end{array}$ & $\begin{array}{l}\text { No. of } \\
\text { leaves/ } \\
\text { plant }\end{array}$ & $\begin{array}{l}\text { Length of } \\
\text { longest } \\
\text { leaf }\end{array}$ & $\begin{array}{l}\text { No. of } \\
\text { infloresce } \\
\text { nces / } \\
\text { plant }\end{array}$ & $\begin{array}{l}\text { No. of } \\
\text { flower/ } \\
\text { infloresce } \\
\text { nce }\end{array}$ & $\begin{array}{l}\text { No. of } \\
\text { fruit/ } \\
\text { infloresce } \\
\text { nces }\end{array}$ & $\begin{array}{l}\text { Diameter } \\
\text { of fruit } \\
(\mathrm{cm})\end{array}$ & $\begin{array}{l}\text { Fresh } \\
\text { weight of } \\
\text { individual } \\
\text { fruit }\end{array}$ & $\begin{array}{l}\text { TSS } \\
(\%)\end{array}$ & $\begin{array}{l}\text { No. of } \\
\text { seeds/ } \\
\text { fruit }\end{array}$ & $\begin{array}{l}\text { Yield } \\
\text { /plot (g) }\end{array}$ & $\begin{array}{l}\text { Yield } \\
\text { (t/ha) }\end{array}$ \\
\hline $\mathrm{A}_{1} \mathrm{C}_{1}$ & $22.20 \mathrm{~d}$ & $37.17 \mathrm{e}$ & $20.10 \mathrm{e}$ & $9.11 \mathrm{~d}$ & $5.22 \mathrm{~d}$ & $5.88 \mathrm{c}$ & $3.50 \mathrm{~b}$ & $15.33 \mathrm{f}$ & $15.35 \mathrm{~d}$ & $180.0 \mathrm{~b}$ & $223.1 \mathrm{f}$ & $13.38 \mathrm{e}$ \\
\hline $\mathrm{A}_{2} \mathrm{C}_{1}$ & $29.23 \mathrm{a}$ & $45.33 b$ & $25.52 b$ & $15.25 \mathrm{~b}$ & $7.44 \mathrm{~b}$ & 7.22ab & $4.20 \mathrm{a}$ & $19.14 d$ & $18.11 \mathrm{~b}$ & $120.0 \mathrm{c}$ & $317.9 \mathrm{~d}$ & $19.07 \mathrm{~b}$ \\
\hline $\mathrm{A}_{3} \mathrm{C}_{1}$ & $24.40 \mathrm{c}$ & $43.11 \mathrm{c}$ & $21.60 \mathrm{~d}$ & $13.33 \mathrm{c}$ & $6.55 \mathrm{c}$ & $6.12 \mathrm{c}$ & $4.00 \mathrm{ab}$ & $17.32 \mathrm{e}$ & $16.92 \mathrm{c}$ & $217.0 \mathrm{a}$ & $266.2 \mathrm{e}$ & $15.96 \mathrm{~d}$ \\
\hline $\mathrm{A}_{1} \mathrm{C}_{2}$ & $22.83 \mathrm{~d}$ & $38.97 d$ & $22.47 \mathrm{~cd}$ & $12.56 \mathrm{c}$ & $5.69 \mathrm{~d}$ & $6.11 \mathrm{c}$ & $3.61 \mathrm{~b}$ & $21.33 \mathrm{c}$ & $16.57 \mathrm{c}$ & $185.0 \mathrm{~b}$ & $327.0 \mathrm{c}$ & $16.51 \mathrm{c}$ \\
\hline $\mathrm{A}_{2} \mathrm{C}_{2}$ & $30.33 a$ & $47.36 \mathrm{a}$ & $27.64 \mathrm{a}$ & $16.66 \mathrm{a}$ & $8.99 a$ & $7.68 \mathrm{a}$ & $4.30 \mathrm{a}$ & $25.19 \mathrm{a}$ & $18.98 \mathrm{a}$ & $118.0 \mathrm{c}$ & $482.6 \mathrm{a}$ & $24.37 \mathrm{a}$ \\
\hline $\mathrm{A}_{3} \mathrm{C}_{2}$ & $26.98 b$ & $43.11 \mathrm{c}$ & $23.56 \mathrm{c}$ & $14.55 \mathrm{~b}$ & $7.17 b c$ & $7.12 b$ & $4.50 \mathrm{a}$ & $23.16 \mathrm{~b}$ & $17.01 \mathrm{c}$ & $217.0 \mathrm{a}$ & $385.6 \mathrm{~b}$ & $19.47 b$ \\
\hline LSD at $5 \%$ & 1.34 & 0.79 & 1.34 & 0.90 & 0.79 & 0.49 & 0.53 & 0.38 & 0.43 & 9.40 & 8.29 & 0.53 \\
\hline $\begin{array}{l}\text { Level of } \\
\text { significance }\end{array}$ & $*$ & $*$ & $*$ & $*$ & $*$ & $*$ & $*$ & $*$ & $*$ & $*$ & $*$ & $*$ \\
\hline
\end{tabular}

Same letter indicates no significance within the values at $5 \%$ level of significance *indicates $5 \%$ level of significance

$\begin{array}{lll}\mathrm{A}_{1}=\text { RABI strawberry }-1 & \mathrm{~A}_{2}=\text { New York, USA } & \mathrm{A}_{3}=\text { Kagawa, Jp } \\ \mathrm{C}_{1}=\text { Pot condition } & \mathrm{C}_{2}=\text { Field condition } & \end{array}$ $\mathrm{C}_{2}=$ Field condition

As Kagawa, Jp 


\section{No. of flower/inflorescence}

Statistically significant variations were found in number of flowers per inflorescence due to accession effect. The highest (8.21) number of flowers per inflorescence was recorded from accession-2 (New York, USA) and the lowest (5.45) was found in accession-1 (Table 1). A significant change in respect of no. flower of per inflorescences was noticed due to the effect growing condition of strawberry. It was found to be the maximum (7.28) in field condition and the minimum (6.40) was observed in pot condition (Table.2). A significant combined effect of planting condition and different strawberry accession was observed. Field condition with accession-2 (New York, USA gave the highest (8.99) number of flowers per inflorescences and the lowest (5.22) was found in respect of pot condition with accession-1 (RABI strawberry-1) (Table 3).

\section{Number of fruit per inflorescences}

The accessions had significant effect on number of fruit per inflorescences. Accession-2 New York, USA gave the highest number of fruit per inflorescences (7.45) while RABI-1 obtained the lowest value (5.99) (Table1). This result agrees with of Paul et al. (2017). The two planting condition showed significant effect on number of fruit per inflorescences. The field condition gave the highest number of fruit per inflorescences (6.97) and the pot condition gave the lowest (6.41) value (Table 2). There was a significant difference in the number of fruit per inflorescences due to combined effect. The highest number of fruit per inflorescences (7.68) was obtained from strawberry accession New York, USA in field condition and the lowest (5.88) was found in RABI-1 accession in pot condition (Table 3).

\section{Diameter of fruit $(\mathbf{c m})$}

Different accessions showed highly significant variations in respect of diameter of fruit. The maximum diameter of fruit $(4.25 \mathrm{~cm}$ ) was found both in accession-2 (New York, USA) and accession-3. The minimum diameter $(3.56 \mathrm{~cm})$ was observed from accession-1 (RABI strawberry-1) (Table1). The planting effect had significant variances in respect of diameter of fruit. The highest $(4.14 \mathrm{~cm})$ diameter was recorded at field condition while the lowest $(3.90 \mathrm{~cm}$ ) was in pot condition (Table 2). Insignificance variation was found in respect of diameter of fruit by the combined effect of accession and planting condition. The highest $(4.50 \mathrm{~cm})$ diameter was found in accession-3 (Kagawa, Jp) in field condition which was statistically similar with accession-2 (New York, USA) both in field and pot condition. Conversely, the lowest diameter $(3.50 \mathrm{~cm})$ was observed from accession-1 (RABI strawberry-1) raised in pot condition (Table 3).

\section{Fresh weight of individual fruit}

There was a significant difference in fresh weight of fruit at harvest due to different accession. The highest fresh weight of fruit $(22.17 \mathrm{~g})$ was obtained from accession-2 (New York, USA) and the lowest (18.33 g) was found in accession-1 (Table 1). This result agrees with Paul et al., (2017). In field growing condition strawberry gave the superior $(23.23 \mathrm{~g}$ ) result but in pot condition it gave inferior $(17.26 \mathrm{~g})$ result in case of individual fresh weight of fruit. There was a significant difference between them (Table 2). The individual fresh weight of fruit at harvest was significantly influenced. The highest individual weight of fruit $(25.19 \mathrm{~g})$ was noted at accession-2 (New York, USA) grown in field condition and the lowest (15.33g) were found in accession-1 (RABI strawery1) in pot condition (Table 3).

\section{TSS content (\%)}

Total soluble solid (TSS) had changed significantly due to accession effect. Accession-2 (New York, USA) revealed superiority (18.54\%) and accession-1 (RABI strawberry-1) showed inferiority (15.96\%) in case of TSS content in fruit (Table1). This result was also similar with Paul et al. (2017). There were statistically significant differences in TSS content due to the effect of planting condition. Strawberry of field condition showed better (17.52\%) TSS content than of pot (16.79\%) condition (Table 2). The combined effect also had significant effect on Total soluble solids. Accession-2 (New York, USA) grown in field gave the number maximum TSS (18.98) while accession-1 (RABI strawberry-1) grown in pot estimated the lowest (15.35) value (Table 3). 


\section{No. of seeds/fruit}

A significant variation was observed in number of seeds per fruit as affected by the accessions. The highest (217.0) number of seeds per fruit was observed from accession-3 (Kagawa, Jp) and the lowest (119.0 g) was found in accession-2 (New York, USA) (Table 1). There is no significant difference between pot and field condition in respect of number of seeds per fruit (Table 2). The maximum number of seed per fruit was noted strawberry grown in field condition (173.33) and minimum was in pot condition (172.33). The combined effect of accession and planting conditions had significant variances in respect of number of seeds per fruit. The highest (217.0) number of seeds per fruit was recorded from accession-3 (Kagawa, Jp) grown both in pot and field condition. On the other hand, the lowest (118.0) was found in accession-2 (New York, USA) in field condition (Table 3).

\section{Yield/plot (g)}

Yield (g/plot) was found to be statistically significant due to the effect of accession (Table 1). Accession-2 (New York, USA) produced the highest $(400.3 \mathrm{~g})$ yield and the lowest yield was recorded $(275.0 \mathrm{~g})$ in accession-1 (Table 1). A statistical difference was revealed by the effect of planting condition on yield per plot. The highest $(398.41 \mathrm{~g})$ yield was observed in field condition while the lowest $(269.07 \mathrm{~g})$ was found in pot condition (Table 2). Different treatment combination showed significant effect on the yield of per plot. The treatment of accession-2 (New York, USA) in field condition gave the highest yield per plot (482.6 g) and accession-1 (RABI strawberry-1) raised in pot condition gave the lowest $(223.1 \mathrm{~g})$ yield per plot.

\section{Yield (t/ha)}

There were statistically significant differences in yield per hectare due to the different accession effect. Accession-2 (New York, USA) gave the highest (21.72 t/ha) yield per hectare. On the other hand, the lowest (14.94 t/ha) yield was observed from accession-1 (Table 1). Yield (t/ha) was found to be statistically significant between two growing conditions (Table 2). In field condition, the highest (20.12 t/ha) yield was recorded and the yield was obtained $(16.14 \mathrm{t} / \mathrm{ha}$ ) in pot condition (Table 2). It was observed that the combined effect of different accession and growing condition on yield were highly significant (Table 3). The highest yield (24.37t/ha) was observed at accession-2 (New York, USA) in field condition and the lowest yield (13.38t/ha) was produced in accession-1(RABI strawberry-1) raised in pot condition (Table 3).

The combined effect of different accession and growing condition on yield and yield contributing characters were highly significant. The highest yield $(24.37 \mathrm{t} / \mathrm{ha}$ ) was observed at accession-2 (New York, USA) in field condition and the lowest yield (13.38t/ha) was produced in accession-1(RABI strawberry-1) raised in pot condition. Considering the findings of the experiments under study, the following practices may be recommended for strawberry production in Bangladesh: Accession-2 (New York, USA) and field growing condition are mostly suitable for production in Bangladesh. However, further investigation is necessary to same experiments.

\section{ACKNOWLEDGEMENT}

The authors are very much grateful to the authority of Bangladesh nuclear Institute of Agriculture for allowing conducting the experiment in the research field.

\section{CONFLICH OF INTEREST}

There are no conflicts of interest in this study. 


\section{REFERENCES}

1. Chowdhury AN, Nargis A, Rahman MZ, Alam AKMS, Ibrahim M and Akhter S, 2013. Freezing adaptability and chemical composition of strawberry (Fragaria $x$ ananassa) in Bangladesh. Journal of Environmental Science, Toxicology and Food Technology, 7(4): 50-54.

2. FAO, 2018. http://faostat.fao.org.

3. FAOSTAT, 2018. http://faostat.fao.org.

4. Gomez KA and Gomez AA. 1984. Stasistical Procedure for Agricultural Research (2nd ed.). John, Willey and Sons, Singapore. pp. 28-192. Hannum S, 2004. Potential impact of strawberries on human health: A review of the science. Nutritional Sciences, 44: 1-17.

5. Hossain MM, 2009. Bangladeshe strawberry chas (In Bengali) (Third Edition). Somokal Publication, Dhaka, Bangladesh, 5-9.

6. Jensen RJ, Hancock JF Jr, 1982. Multivariate relationships among California strawberries. Bulletin of the Torrey Botanical club. 109: 136-47.

7. Paul C, Gomasta J and Hossain MM, 2017. Effects of planting dates and variety on growth and yield of strawberry. International journal of Horticulture, Agriculture and Food science, 1(4): 1-16.

8. Ram RB, Maurya D, Dwivedi DH and Chaturvedi SK, 2009. Effect of different spacing on growth, flowering, fruiting, yield and quality of Strawberry (Fragaria $x$ ananassa) cv. Chander. Advanced Plant Science, 22(2): 517-519.

9. Sharma NC, Sharma SD and RS Spehi, 2013. Effect of plastic mulch color on growth, fruiting and fruit quality of strawberry under polyhouse cultivation. International Journal of Bio-resource and Stress Management, 4(2): 314-315.

10. Sharma RR, 2002. Growing strawberries. International Book Distributing Company, Lucknow, India.

11. Singh GH and R Asrey, 2009. Growth, earliness and fruit yield of micro-irrigated Strawberry as affected by planting time and mulching in semi-arid regions. Indian Journal of Horticulture, 62(2): 148151. 